\title{
SATISFACTION WITH LIFE AND INFORMAL AND FORMAL SOURCES OF SUPPORT AMONG PEOPLE WITH DISABILITIES
}

Slavica BLAŽEKA KOKORIĆ, Gordana BERC, Silvia RUSAC

Faculty of Law, Zagreb

UDK: 159.923.33-056.26(497.5):364.046.2

Izvorni znanstveni rad

Primlieno: 1. 10. 2010.

This study shows the results of the research on satisfaction with life and informal and formal sources of support among people with disabilities in the Republic of Croatia. The purpose of this study is to contribute to a better understanding of differences in life and social support satisfaction among people with disabilities according to their specific social-demographic characteristics. The research was conducted by means of an interview of 689 people with disabilities. The data, obtained from a weighted sample of 391 people, were analyzed by methods of descriptive statistics, variance analysis, t-test and correlation analysis. The results show that people with disabilities are the most satisfied with informal sources of support (immediate family, friends) and the least satisfied with the support of non-profit organizations and local and national authorities. It was determined that there are significant differences in the life satisfaction among people with disabilities in terms of all the observed characteristics, except for the sex and the size of the place of residence. Moreover, the level of their life satisfaction is closely related to almost every source of social support.

Keywords: people with disabilities, social support, satisfaction with sources of support, life satisfaction

Slavica Blažeka Kokorić, Faculty of Law, Department of Social Work, Nazorova 51, 10000 Zagreb, Croatia.

E-mail: slavica.blazeka@pravo.hr 


\section{INTRODUCTION}

According to the fundamental principle of the "Council of Europe Action Plan to promote the rights and full participation of people with disabilities in society", adopted by the Council of Europe in 2006, the obligation of the society is to ensure that all the citizens feel consequences of disability as little as possible by means of getting active support for a healthy way of living, adequate social welfare, rehabilitation, a safer environment and a community which is ready to give support (Kosor, 2006). The above mentioned Action Plan is aimed at improving the quality of life of people with disabilities in Europe, in the period from 2006 to 2015. Since 2007, the Republic of Croatia is a signatory country of the Convention on the Rights of Persons with Disabilities, which obliges it to plan strategic policies in order to support an independent living of people with disabilities and ensure an improvement of the quality of life in all areas. On the basis of the Census of population of the Republic of Croatia (2001), which for the first time included a few questions exclusively for people with disabilities, it was determined that in Croatia there are 429,421 persons with disabilities (9.7\% of the total population). Still, there has not been enough research in Croatia on their position and quality of life, and the level of their satisfaction with the availability and quality of different sources of formal and informal support. One of just a few research projects in this field was conducted by Marinić i Brkljačić (2008), who concluded that people with physical disabilities compared to people without disabilities are significantly less satisfied with their health and physical safety, relationships with family members and friends as well as with their experience of acceptance by the wider community.

Equal participation of people with disabilities in Croatian society remains far removed from the reality of their dissatisfied position in society, suggests Urbanc (2005). Urbanc highlights the nature of the specific obstacles that challenge people with disabilities, when they look for support to exercise their rights for equal participation in Croatia. Urbanc says that health, educational and social systems are largely bureaucratized, which means that beneficiaries find many rights difficult to understand and exercise. On the other hand, the analysis of indicators of the services and resources distribution process in the Croatian social welfare system shows that social support as well as transfers are symbolic and unequally distributed to beneficiaries, and also that specific living expenses of people with disabilities are very high (Leutar and Milić Babić, 2006), which puts them in a particularly vulnerable position. Therefore, social support is an important factor in the life of people with disabilities. A review of literature shows 
DRUŠ. ISTRAŽ. ZAGREB GOD. 21 (2012),

BR. 1 (115)

STR. 19-38

BLAŽEKA KOKORIĆ, S., BERC, G., RUSAC, S.: SATISFACTION WITH that there are different definitions of social support. Barrera (1986) sees social support through three separate constructive elements: perceived support, social integration and real support. The perceived social support refers to social relation functions, i.e. an individual's perception of how members of his/her social network, if necessary, would ensure sources of emotional and instrumental support. The social integration or the social network refers to the structure of existing social relations and the social network members' number and identity. The real support, i.e. the currently available support, refers to all behaviors which the social network's members use to express their support to the individual.

According to the literature, we can recognize different sources of social support usually divided into formal and informal sources of support. Formal sources include different forms of help in money or in kind from state and other institutions, and informal sources of support refer to the help (financial, material, practical and emotional) received from family members, friends, relatives, neighbors and the like (Leutar et al., 2007). Most people get the biggest part of emotional, material and instrumental help precisely from their family. Past research shows that people with disabilities see primarily informal sources of support as the significant ones in their lives. For instance, the research of support sources for people with physical disabilities (Leutar et al., 2007) showed that people with physical disabilities acknowledge their children and spouse as the most significant source of support, as well as the Church and relatives, while formal sources of support like representatives of authorities on the county or state level, centers for social welfare, and even associations, are estimated to be less important sources of support.

Different authors point out a symbolic financial support for people with disabilities, which is in large disproportion to their specific needs. Allen et al. (2000) reported that more than half of the people with disabilities cannot meet their basic living expenses, and that younger people with disabilities are poorer than the elderly. In general, the literature oriented towards the socio-economic situation of people with disabilities leads to the conclusion that a disability means being at a serious risk of poverty (Leutar, 2006).

When assessing social support, it is important to recognize the key role of the subjective perception of the individual in receipt of support. It must be emphasized that this role is not necessarily correlated with the objective quantity of available support provided by different sources (Janković, 2004). The number of social interactions provides information on the probability of receiving social support, but it does not provide any information on the satisfaction with the received 
DRUŠ. ISTRAŽ. ZAGREB GOD. 21 (2012) BR. 1 (115),

STR. 19-38

BLAŽEKA KOKORIĆ, $S$. BERC, G., RUSAC, S.: SATISFAC'TION WITH... support. Sometimes, a single social relation, if it is significant to the individual, can help to decrease the risk of negative effects of stress (Sarason et al., 1987).

The better the quality of social support for people with disabilities generally, the more positive effect on their life. Such quality support increases personal resources, the level of somatic and psychic health and the overall personal satisfaction with one's life (Janković, 2004).

Life satisfaction refers to a global evaluation of personal life and it is considered a cognitive component of subjective benefit, which is made of one more emotional component mood or emotions (Penezić, 2006). Literature shows that there are numerous studies which comprised the concept of life satisfaction among people with disabilities. The results of a study on the employment of people with disabilities in Croatia showed that employed persons with disabilities are more satisfied with their lives than unemployed persons (Leutar and Milić Babić, 2008). By using other work potentials, employed persons with disabilities have an opportunity to be active members of the society, provide for themselves and their families, and in that way see themselves as equal members of the society. Furthermore, a study persons with muscular dystrophy and multiple sclerosis participated in revealed some interesting results on the life satisfaction of people with disabilities (Chen and Crewe, 2009). The psychological variable of hope and acceptance of disability, as well as spiritual benefit, proved to be the best predictors of life satisfaction, while socio-demographic variables proved to be less powerful predictors. Also, it was ascertained that people with disabilities who had never been married or were divorced considered their life satisfaction worse in comparison to those who were married, which are results that have been obtained by other studies as well (Allen et al., 2000; Leutar et al., 2007). In addition, Hampton (2001) reports that individuals who perceive that they have a higher support of their family, relatives, friends and community and public services, are more satisfied with their lives than those who do not see that support as important.

A high quality of public services attenuates the effects of users' difficult socio-economic situation and directly influences a subjective well-being of people. In order to increase the quality of public services, an important issue is the way in which a service is provided. Efforts of public institutions to create openness, transparency and responsibility would increase the confidence of citizens in them, and that is the second standard of the quality of the society (Watson et al., 2010).

Given the fact that past theoretical and empiric findings on the perception of social support and life satisfaction are mainly oriented towards the population of persons with dis- 
DRUŠ. ISTRAŽ. ZAGREB GOD. 21 (2012),

BR. 1 (115)

STR. 19-38

BLAŽEKA KOKORIĆ, S., BERC, G., RUSAC, S.: SATISFACTION WITH abilities in general, the purpose of this study is to contribute to a better understanding and a detailed description of differences in the satisfaction with life and social support of people with disabilities through the acknowledgement of their specific position according to the observed socio-demographic characteristics. In doing so, we wish to give extra attention to the raising of awareness of differences in satisfaction with life and social support of people with disabilities, depending on their sex and age perspective, type of disability, subjective assessment of severity of disability, material status, work status and size of the place of residence in which a person with disability lives.

\section{RESEARCH OBJECTIVE AND PROBLEMS}

The general objective of this research is to examine the satisfaction with informal and formal sources of social support and life satisfaction among people with disabilities in the Republic of Croatia according to their socio-demographic characteristics.

In the framework of the above mentioned objective, we tried to provide answers to the following issues:

1. to identify the level of satisfaction with different informal and formal sources of support among people with disabilities,

2. to identify if there are any statistically significant differences in the satisfaction with social support of people with disabilities, according to the observed socio-demographic characteristics of people with disabilities,

3. to identify if there are any statistically significant differences in the life satisfaction of people with disabilities, according to their socio-demographic characteristics,

4. to examine the correlation between life satisfaction and the satisfaction with different sources of social support among people with disabilities.

\section{Research hypotheses}

Given the past research results, the following hypotheses have been set up:

H1 There are significant differences between the satisfaction with formal and informal sources of support and the life satisfaction of people with disabilities in terms of their socio-demographic characteristics.

H2 There are different levels of significant correlations between life satisfaction and the satisfaction with formal and informal sources of social support among people with disabilities. 
DRUŠ. ISTRAŽ. ZAGREB GOD. 21 (2012), BR. 1 (115),

STR. 19-38

BLAŽEKA KOKORIĆ, S., BERC, G., RUSAC, S.: SATISFACTION WITH

\section{METHOD}

\section{Sample of the research}

In the sample of the research were included 391 people with differing types of disabilities. In the observed sample $51 \%$ are men and $49 \%$ are women. The younger adults' age group (ages 18 to 35 ) has $32 \%$ of respondents, the middle adults' age group (ages 36 to 55 ) has $38.9 \%$ of respondents, and the elder adults' age group (56 and more) has $29.1 \%$ of respondents.

Regarding the type of disability, people with physical disabilities are the most represented (50\%), followed by people with multiple disabilities (24\%), with visual impairments (9\%), with intellectual impairments $11 \%$, and with hearing impairments $(6 \%)$.

\section{Procedure}

In the research, a two stage sample was drawn from the 689 participants with disabilities. 28 Centers from 107 Centers of Social Welfare and their branch-offices in Croatia ${ }^{1}$ were selected by simple random sample. In the second stage, a sample of 25 persons with disabilities resident within the bounds of jurisdiction of each of the 28 centers and their branch offices, were collected. In consideration of the significant imbalance of people with disabilities who live on the territorial jurisdiction representing the 28 Centers of Welfare and their branch offices, the next step, approached with sensitivity, was the weighting of the sample. This was done in order to adjust the relative contributions of the respondents. After applying the aforementioned weighting procedure the total effective sample size resulted in a total of 391 respondents.

The research was conducted in the form of a survey during 2008 and 2009.

\section{Variables}

- Socio-demographic variables refer to the gender of the respondents, the age (categories: young adulthood = ages 18-35; middle adulthood = ages 36-55; late adulthood $=$ ages 56 and more), the type of disability (categories: visual impairments, hearing 
DRUŠ. ISTRAŽ. ZAGREB GOD. 21 (2012),

BR. 1 (115)

STR. 19-38

BLAŽEKA KOKORIĆ, S., BERC, G., RUSAC, S.: SATISFACTION WITH impairments, physical disability, intellectual impairments, multiple disabilities), ${ }^{2}$ the subjective assessment of severity of disability (categories: minor, moderate, serious, very serious), ${ }^{3}$ the work status (categories: employed, unemployed, retired, other), the material status (categories: very good and good; average; bad; very bad), the size of the place of residence (smaller towns with 1,000 to 10,000 inhabitants; middle towns with $10,001-100,000$ inhabitants; big towns - more than 100,000 inhabitants).

- Satisfaction with formal and informal sources of social support in everyday life is measured by a scale which was constructed for the needs of this research. On a scale of 1 to 5 (1 - very unsatisfied, 2 - unsatisfied, 3 - neither satisfied nor unsatisfied, 4 - satisfied and 5 - very satisfied) the respondents expressed their satisfaction with the quantity of support received from the following individuals or institutions: spouse, parents, children, relatives, neighbors, Church, non-profit organizations, social welfare centers experts, school and preschool institutions experts, health professionals, municipal authorities representatives, county authorities representatives, state authorities representatives.

- Present life satisfaction is measured by a scale of 1 to 5 , which is reversely coded compared to the social support satisfaction scale $(1$ - very satisfied, 2 - satisfied, 3 - neither satisfied nor unsatisfied, 4 - unsatisfied and 5 - very unsatisfied).

\section{Data analysis}

The methods of descriptive statistics, variance analysis, t-test and correlation analysis were used for data analysis.

\section{RESULTS AND DISCUSSION}

\section{Satisfaction with formal and informal sources of support}

The obtained results on the satisfaction with different sources of support show that people with disabilities are the most satisfied with informal sources of support by immediate family and friends. It is determined that they are the most satisfied with the support of their spouse, then with children's support, parents' support, and finally with friends' support. These findings are in accordance with results of earlier researches which also showed that people with disabilities find the highest support to face everyday problems in their immediate family (their children, spouse and parents), the spouse having an especially significant role in giving support (Leutar and Štambuk, 2007; Leutar et al., 2008). 


\begin{tabular}{lrrrrrr}
\hline Sources of support & $\mathrm{N} 4$ & $\mathrm{M}$ & $\mathrm{SD}$ & Min. & Max. & Rang \\
\hline Spouse & 165 & 4.20 & 1.12 & 1 & 5 & 1 \\
Parents & 235 & 4.14 & 1.09 & 1 & 5 & 3 \\
Children & 192 & 4.17 & 1.01 & 1 & 5 & 2 \\
Friends & 344 & 3.57 & 1.10 & 1 & 5 & 4 \\
Relatives & 347 & 3.42 & 1.06 & 1 & 5 & 6 \\
Neighbors & 330 & 3.29 & 1.05 & 1 & 5 & 9 \\
Health professionals & 353 & 3.55 & 1.06 & 1 & 5 & 5 \\
School and preschool institutions experts & 183 & 3.38 & 1.19 & 1 & 5 & 8 \\
Social welfare centers experts & 336 & 3.39 & 1.14 & 1 & 5 & 7 \\
Church & 293 & 3.22 & 1.23 & 1 & 5 & 10 \\
Non-profit organization & 228 & 3.00 & 1.29 & 1 & 5 & 11 \\
Municipal authorities representatives & 272 & 2.62 & 1.14 & 1 & 5 & 12 \\
County authorities representatives & 276 & 2.42 & 1.07 & 1 & 5 & 13 \\
State authorities representatives & 242 & 2.19 & 1.11 & 1 & 5 & 14 \\
\hline
\end{tabular}

\section{(1) TABLE 1}

Comparison of the satisfaction between different formal and informal sources of support
It is interesting to note that satisfaction with the support of extended family and relatives has a lower rank than satisfaction with the support of health professionals, which is obviously recognized as very valuable by people with disabilities. The support of the Centre for Social Welfare experts, school and preschool institutions is estimated to be higher than that of the support from neighbors. On the other hand, findings of earlier researches lead to the conclusion that people with disabilities are in general less satisfied with formal than informal sources of support. For instance, Leutar et al. (2008) state that a significant number of people with disabilities do not receive support and understanding in terms of the social system services and institutions which should ensure them a certain type of service and support. The network of family and goodneighbor help was not confirmed in our research as an important source of satisfaction compared to the above mentioned formal sources of support. This concurs with some of the recent sociological researches which indicate a trend of weakening of family bonds and development of modernization of the society, as a consequence of which family bonds lose their value and their importance weakens as a source of social support (Leutar, 2006). On the other hand, satisfaction with the support of the Church is ranked 10 (out of 14). However, Leutar et al. (2008) say that families of people with disabilities, when formal sources of support are in question, get the highest support from the Church which, although it does not always appear as a practical help, represents an important source of spiritual and emotional support. The satisfaction with non-profit organizations is ranked 11, which proves that the non-governmental sector is still not confirmed enough nor recognized as a possible source of support for people with disabili- 
DRUŠ. ISTRAŽ. ZAGREB GOD. 21 (2012),

BR. 1 (115)

STR. 19-38

BLAŽEKA KOKORIĆ, S., BERC, G., RUSAC, S.: SATISFACTION WITH ties in Croatia. Although $46.4 \%$ of the respondents are said to be members of a certain association, it is obvious that the satisfaction with this source of support is not as represented as one would expect, given the findings of other researches which show that people with disabilities who are members of an association point out the importance of support they receive from it (Bayley and Gorančić-Lazetić, 2006; Leutar et al., 2008).

The least satisfaction was expressed by respondents for the support of authorities' representatives on municipal, county and state level, where the level of satisfaction falls as the level of authority increases. This concurs with findings of some other authors, like Leutar and Štambuk (2007), who explain that the dissatisfaction with support and understanding of the authority representatives is related to the general dissatisfaction with the existing economic and social status. The obtained values and differences of satisfaction evaluation of certain sources of support can be interpreted as a possible reflection of different expectations one has of a particular source of support, where a higher dissatisfaction is related to unfulfilled expectations.

\section{Differences in satisfaction with formal and informal sources of support depending on socio-demographic characteristics of people with disabilities}

Given the big number of the observed formal and informal sources of support, the results arrived at by summing up the obtained significant differences according to the observed socio-demographic characteristics of people with disabilities will be presented in this part.

On the basis of the t-test results, it was determined that no significant differences in the satisfaction of people with disabilities had been found as far as the gender was concerned in neither of the observed formal and informal sources of social support $(p>0.05)$. In other words, the findings of this research did not confirm some other authors' statements on an unfavorable position of women with disabilities compared to men with disabilities, women with disabilities often facing double or multiple discriminations (Wang et al., 2002).

Further results of variance analysis regarding differences in the satisfaction with formal and informal sources of support indicate the following: as far as the age of people with disabilities is concerned, it was determined that there are significant differences in the satisfaction with parents' support $(F=6,980$; $\mathrm{p}=0.001$ ) and the satisfaction with the support of county authorities $(\mathrm{F}=3,969 ; \mathrm{p}=0.020)$. It has also been determined that the middle adults (ages 35-55) express a lower level of satisfaction with parents' support $(\mathrm{M}=3.93 ; \mathrm{SD}=1.12)$ in compari- 
DRUŠ. ISTRAŽ. ZAGREB GOD. 21 (2012) BR. 1 (115),

STR. 19-38

BLAŽEKA KOKORIĆ, $S$. BERC, G., RUSAC, S.: SATISFAC'TION WITH... son to the young adults (ages 18-35) $(\mathrm{M}=4.40 ; \mathrm{SD}=1.01)$. At the same time, people with disabilities in late adulthood $(>56)$ find the support of county authorities much less available $(\mathrm{M}=2.21$; $\mathrm{SD}=0.95)$ compared to the middle adults $(\mathrm{M}=2.66 ; \mathrm{SD}=1.05)$. In general, it was determined that the level of satisfaction with support is the lowest among people in late adulthood, which concurs with findings of other researches. For instance, Petrak et al. (2006) say that among the elderly there is a reduction of social network, having as a consequence a smaller social support.

According to the type of disability, it was determined that people with multiple disabilities show a lower level of satisfaction $(\mathrm{F}=5,058 ; \mathrm{p}=0.001)$ with friends' support $(\mathrm{M}=3.25 ; \mathrm{SD}=0.92)$ than people with physical disabilities $(\mathrm{M}=3.75 ; \mathrm{SD}=1.05)$ and hearing impairments $(\mathrm{M}=4.08 ; \mathrm{SD}=0.97)$.

Regarding a subjective assessment of the severity of disability, it was found that people who experience their disability as serious are much less satisfied $(F=2,683 ; p=0.047)$ with the support of their health professionals $(\mathrm{M}=3.40$; $\mathrm{SD}=1.10)$ compared to people who find their disabilities relatively minor $(\mathrm{M}=3.95 ; \mathrm{SD}=0.89)$. These findings are largely unsurprising as people with multiple disabilities are often in greater need of medical support than those with lesser disabilities and as such have greater contact with medical staff.

These findings are expectable since people with multiple disabilities are more often in contact with medical staff because they need medical help more frequently than people with lower level of disability.

The work status of people with disabilities proved to be relevant for the perception of satisfaction with spouse's support $(\mathrm{F}=5,269 ; \mathrm{p}=0.002)$ and extended family's support $(\mathrm{F}=3,965$; $\mathrm{p}=0.008$ ). It was found that unemployed people with disabilities are much less satisfied with spouse's support $(\mathrm{M}=3.73$; $\mathrm{SD}=1.42)$ than those employed $(\mathrm{M}=4.46 ; \mathrm{SD}=0.77)$ and retired people with disabilities $(\mathrm{M}=4.34 ; \mathrm{SD}=0.96)$. Also, a lower level of satisfaction with extended family's support is expressed by retired people with disabilities $(\mathrm{M}=3.29$; $\mathrm{SD}=1.04)$ and those unemployed $(\mathrm{M}=3.38$; $\mathrm{SD}=1.09)$ compared to the employed $(\mathrm{M}=3.93 ; \mathrm{SD}=0.85)$. It is obvious that employed people with disabilities are in a more favorable position than the unemployed, which was also confirmed by other researches (Leutar and Milić Babić, 2008). Employed people with disabilities have an opportunity to be active members of the society, to provide for themselves and their families, which influences their self-respect and a higher satisfaction with spouse's support. Moreover, people with disabilities broaden through work the circle of people they meet every day, which enriches and completes their social life. On the other hand, unemployed 
DRUŠ. ISTRAŽ. ZAGREB GOD. 21 (2012), BR. 1 (115)

STR. 19-38

BLAŽEKA KOKORIĆ, S., BERC, G., RUSAC, S.: SATISFACTION WITH and retired people with disabilities obviously make fewer social contacts, which can have as a consequence less satisfaction with the support of the environment. Furthermore, it is also known that unemployment among people with disabilities can result in a state of depression, a loss of self-esteem and a lower level of self-respect (Bayley and Gorančić-Lazetić, 2006), which can decrease their satisfaction with the social support.

As to the criterion of material status among people with disabilities, the biggest number of differences in satisfaction with the observed formal and informal sources of support was found: differences were established in perception of the satisfaction with relatives' support $(F=9,599 ; p=0.000)$, friends' support $(F=16,290 ; p=0.000)$, neighbors' $(F=6,427 ; p=0.001)$, the Church's $(F=4,972 ; p=0.020)$, municipal authorities representatives' ( $\mathrm{F}=3,669 ; \mathrm{p}=0.013)$ and county authorities representatives' support $(\mathrm{F}=3,596 ; \mathrm{p}=0.010)$. People with disabilities who see their material status as very bad and bad, perceive a lower level of support of relatives, friends and neighbors compared to people of average, good and very good material status. It is interesting to note that the highest satisfaction with support of the Church, municipal authorities representatives and county authorities representatives is shown precisely by people of good/very good material status (support of the Church $\mathrm{M}=3.88$; $\mathrm{SD}=0.94$; support of municipal authority $\mathrm{M}=3.37$; $\mathrm{SD}=1.13$; support of county authority $\mathrm{M}=3.10 ; \mathrm{SD}=1.14$ ). At the same time, people who see their material status as very bad are much less satisfied with the support of the Church $(\mathrm{M}=2.84$; $\mathrm{SD}=1.36)$ and municipal authorities $(\mathrm{M}=2.45 ; \mathrm{SD}=1.23)$. People who see their material status as bad, feel less satisfied with the support of the Church ( $\mathrm{M}=2.97 ; \mathrm{SD}=1.30)$, and with county authorities as well $(\mathrm{M}=2.26$; $\mathrm{SD}=0.95)$. Beside the above mentioned, people with disabilities who see their material status as average, show much more dissatisfaction with support of municipal authorities $(\mathrm{M}=2.58 ; \mathrm{SD}=1.12)$ and county authorities $(\mathrm{M}=2.42 ; \mathrm{SD}=1.02)$ compared to people of good and very good material status.

As to the size of the place where people with disabilities live, a big number of significant differences was also obtained regarding satisfaction by the following sources of support: relatives $(\mathrm{F}=4,371 ; \mathrm{p}=0.003)$, neighbors $(\mathrm{F}=5,054 ; \mathrm{p}=0.070)$, non-governmental organizations $(\mathrm{F}=3,784 ; \mathrm{p}=0.024)$ and school and preschool institutions experts $(\mathrm{F}=4,802 ; \mathrm{p}=0.009)$. Less satisfaction with support of relatives is shown by people with disabilities who live in big cities with over 100,000 inhabitants $(\mathrm{M}=3.18 ; \mathrm{SD}=1.29)$ and smaller places with up to 10,000 inhabitants $(\mathrm{M}=3.32 ; \mathrm{SD}=1.07)$ compared to medium-sized towns of 10,001-100,000 inhabitants, where people with disa- 
DRUŠ. ISTRAŽ. ZAGREB GOD. 21 (2012), BR. 1 (115),

STR. 19-38

BLAŽEKA KOKORIĆ, $S$. BERC, G., RUSAC, S.: SATISFACTION WITH bilities are the most satisfied with support of relatives $(\mathrm{M}=3.65$; $\mathrm{SD}=0.95$ ). Also, people who live in big towns are less satisfied with neighbors' support $(\mathrm{M}=2.85 ; \mathrm{SD}=1.42)$ than people who live in medium-sized towns $(\mathrm{M}=3.48 ; \mathrm{SD}=0.94)$. The least satisfaction is shown with the support of non-governmental organizations by people who live in small towns $(\mathrm{M}=2.76 ; \mathrm{SD}=1.34)$, much less than people living in medium-sized towns $(\mathrm{M}=3.27$; $\mathrm{SD}=1.16$ ).

The obtained results can be explained by the activities of a larger number of associations in urban areas compared to smaller rural areas, so the availability of their services is bigger in urban areas (ex. If they are members of a certain association in the City of Zagreb, people with visual impairments get a free annual pass for public transport). Findings of some other researches indicate an unequal position of people with disabilities who live in smaller places compared to those living in bigger ones. According to UNDP data (Bayley and Gorančić-Lazetić, 2006), people with intellectual disabilities who are not members of associations and who live in smaller places and rural areas do not exercise the same rights, which creates an unfair two-class system.

By summing up the above mentioned, we can conclude that people with disabilities who live in medium-sized towns are, compared to the other groups, the most satisfied with the support of relatives, neighbors and non-governmental sector. On the other hand, in assessing the satisfaction with experts' support from school and preschool institutions, people with disabilities living in medium-sized towns show a lower level of satisfaction with that source of support $(M=3.05$; $S D=1.24)$ than people in bigger towns, where the satisfaction with support in educational institutions is the highest $(\mathrm{M}=4.02 ; \mathrm{SD}=1.31)$.

\section{Life satisfaction among people with disabilities}

The differences in life satisfaction among people with disabilities according to the observed socio-demographic characteristics are shown in Table 2 . As already mentioned, the assessments of life satisfaction are represented on a scale from 1 to 5 , lower values indicating a bigger life satisfaction and vice-versa (contrary to the assessments of the social support satisfaction scale).

In the assessment of life satisfaction among people with disabilities according to age, a statistically significant difference was obtained at the level of $p=0.000$. Scheffe's test was used to establish statistically significant differences between people with disabilities in late adulthood (56 and more) and young adulthood (ages 18-35) at the level of $\mathrm{p}=0.000$, and between people in late adulthood and middle adulthood (ages 36-55) at the 
DRUŠ. ISTRAŽ. ZAGREB GOD. 21 (2012),

BR. 1 (115)

STR. 19-38

BLAŽEKA KOKORIĆ, S., BERC, G., RUSAC, S.: SATISFACTION WITH. level of $p=0.014$. The represented average values in Table 2 show that people with disabilities in late adulthood are significantly less satisfied with life than the other two groups. One of the possible sources of life dissatisfaction among elderly people with disabilities could be their dependence on others, an increased need for support and health problems that inhibit social participation of the elderly (Verbrugge and Yang, 2002).

\begin{tabular}{|c|c|c|c|c|c|c|c|}
\hline \multirow{2}{*}{\multicolumn{2}{|c|}{$\begin{array}{l}\text { Socio-demographic characteristics } \\
\text { of people with disabilities }\end{array}$}} & \multicolumn{6}{|c|}{ Life satisfaction } \\
\hline & & $\mathrm{M}$ & SD & $\mathrm{N}$ & $\mathrm{F}$ & $\mathrm{df}$ & $\mathrm{p}$ \\
\hline Age & $\begin{array}{l}18-35 \\
36-55 \\
56 \text { and more }\end{array}$ & $\begin{array}{l}2.61 \\
2.77 \\
3.12\end{array}$ & $\begin{array}{l}0.96 \\
0.94 \\
0.98\end{array}$ & $\begin{array}{l}121 \\
149 \\
113\end{array}$ & 8.492 & 2 & 0.000 \\
\hline Type of disability & $\begin{array}{l}\text { Visual impair. } \\
\text { Hearing impair. } \\
\text { Physical } \\
\text { Intellectual } \\
\text { Multiple }\end{array}$ & $\begin{array}{l}2.98 \\
2.55 \\
2.72 \\
2.50 \\
3.20\end{array}$ & $\begin{array}{l}1.01 \\
1.04 \\
0.92 \\
0.94 \\
1.00\end{array}$ & $\begin{array}{r}34 \\
22 \\
195 \\
43 \\
91\end{array}$ & 5.969 & 4 & 0.000 \\
\hline $\begin{array}{l}\text { Subjective severity } \\
\text { of disability }\end{array}$ & $\begin{array}{l}\text { Minor } \\
\text { Moderate } \\
\text { Serious } \\
\text { Very serious }\end{array}$ & $\begin{array}{l}2.52 \\
2.50 \\
2.85 \\
3.10\end{array}$ & $\begin{array}{l}1.09 \\
0.82 \\
0.90 \\
1.02\end{array}$ & $\begin{array}{r}44 \\
79 \\
138 \\
124\end{array}$ & 8.059 & 2 & 0.000 \\
\hline Work status & $\begin{array}{l}\text { Employed } \\
\text { Unemployed } \\
\text { Retired } \\
\text { Other }\end{array}$ & $\begin{array}{l}2.17 \\
2.87 \\
2.97 \\
2.78\end{array}$ & $\begin{array}{l}0.76 \\
0.95 \\
0.98 \\
1.11\end{array}$ & $\begin{array}{r}43 \\
160 \\
148 \\
31\end{array}$ & 8.018 & 3 & 0.000 \\
\hline Material status & $\begin{array}{l}\text { Very good and good } \\
\text { Average } \\
\text { Bad } \\
\text { Very bad }\end{array}$ & $\begin{array}{l}1.95 \\
2.65 \\
3.18 \\
3.78\end{array}$ & $\begin{array}{l}0.87 \\
0.86 \\
0.91 \\
0.94\end{array}$ & $\begin{array}{r}33 \\
219 \\
88 \\
36\end{array}$ & 32.461 & 3 & 0.000 \\
\hline Size of the place of res. & $\begin{array}{l}1000-10000 \\
10000-100000 \\
>100000\end{array}$ & $\begin{array}{l}2.82 \\
2.91 \\
2.47\end{array}$ & $\begin{array}{l}0.95 \\
1.01 \\
0.97\end{array}$ & $\begin{array}{r}215 \\
131 \\
31\end{array}$ & 2.505 & 2 & 0.083 \\
\hline
\end{tabular}

(1) TABLE 2

Assessment of life satisfaction according to socio-demographic characteristics of people with disabilities
According to the type of disability, a statistically significant difference was obtained at the level of $p=0.000$. Scheffe's test was used to establish statistically significant differences between people with intellectual disabilities and multiple disabilities $(\mathrm{p}=0.004)$ and physical and multiple disabilities $(\mathrm{p}=0.004)$, and it was established that people with multiple disabilities are much less satisfied with life than the other two groups. It is evident that the combination of different disabilities makes everyday functioning significantly more difficult for people with disabilities (Benjak et al., 2010), which probably influences their life satisfaction.

According to the subjective assessment of severity of disability, a statistically significant difference was obtained at the level 
DRUŠ. ISTRAŽ. ZAGREB BR. 1 (115),

STR. 19-38

BLAŽEKA KOKORIĆ, $S$. BERC, G., RUSAC, S.: SATISFACTION WITH GOD. 21 (2012)

of $p=0.000$. Significant differences were established between people with serious and minor disabilities $(p=0.008)$ and between people with serious and moderate disabilities $(p=0.000)$, where people who see their disability as serious are much less satisfied with life than the other two groups of people. The obtained result is as expected, since the more serious a disability is, the bigger the needs and demands of people with disabilities in everyday life are; in other words, people depend more on other people's help and care, which can have a negative influence on life satisfaction.

According to work status, a statistically significant difference was obtained at the level of $p=0.000$. Significant differences were established between employed and unemployed people $(p=0.000)$ and between employed and retired people $(p=0.000)$, where employed people are much more satisfied with life than the other two groups. The obtained finding concurs with earlier researches (Eden and Aviram, 1993; Leutar and Milić Babić, 2008) which proved that for people with disabilities employment represents not only a way to earn for a living, but also a source of satisfaction and fulfillment in their life.

According to material status, a statistically significant difference was obtained at the level of $p=0.000$. Scheffe's test results show that there are statistically significant differences among all the observed groups of respondents of different material status and it was established that a bad material status is related to a lower level of life satisfaction. Similarly, the research of Watson et al. (2010) showed that variables of deprivation and impossibility to realize basic needs and services are the most related to life satisfaction. For the criterion of the size of the place of residence, there were no statistically significant differences $(p>0.05)$. The $t$-test results also show that in the assessment of the life satisfaction of people with disabilities there are no statistically significant differences according to gender $(\mathrm{t}=-0.370 ; \mathrm{df}=1 ; \mathrm{p}=0.712)$; in other words, men and women with disabilities equally assess life satisfaction (men $\mathrm{M}=2.80$; $\mathrm{SD}=1.01$; women $\mathrm{M}=2.84 ; \mathrm{SD}=0.95$ ).

\section{Correlations between the satisfaction with different formal and informal sources of support and the life satisfaction of people with disabilities}

The results of the correlation analysis represented in Table 3 show that among all the observed sources of support, except for the support of social welfare centers experts, there is a significant positive correlation with the assessment of life satisfaction (a negative sign is the consequence of scale values coding for support and life satisfaction in the opposite sense). 
DRUŠ. ISTRAŽ. ZAGREB GOD. 21 (2012),

BR. 1 (115)

STR. 19-38

BLAŽEKA KOKORIĆ, S., BERC, G., RUSAC, S.: SATISFACTION WITH

(1) TABLE 3

Correlations between satisfaction with

sources of support and

life satisfaction which indicates a relatively weak statistically significant correlation. Consequently, the represented results of the correlation analysis showed that the more people with disabilities are satisfied with formal and informal sources of support, the more they are satisfied with their life. Similar results on the correlation between life satisfaction and social support are obtained by other studies as well. Newsom and Schulz (1996) find that a smaller social support leads to a lower level of life satisfaction, and Wang et al. (2002) state that there is a significant correlation between life satisfaction among men and the support they receive from the family and others, and they point out that a higher social support and a bigger number of social contacts also influence a better assessment of life satisfaction.

\begin{tabular}{lccc}
\hline \multirow{2}{*}{$\begin{array}{l}\text { Correlations } \\
\text { Sources of support }\end{array}$} & \multicolumn{3}{c}{ Life satisfaction } \\
\cline { 2 - 4 } & $\mathrm{r}$ & $\mathrm{p}$ & $\mathrm{N}$ \\
\hline Spouse & $-0.249^{* *}$ & 0.001 & 164 \\
Parents & $-0.228^{* *}$ & 0.000 & 223 \\
Children & $-0.234^{* *}$ & 0.001 & 190 \\
Friends & $-0.413^{* *}$ & 0.000 & 341 \\
Relatives & $-0.282^{* *}$ & 0.000 & 343 \\
Neighbors & $-0.300^{* *}$ & 0.000 & 348 \\
Health professionals & $-0.140^{* *}$ & 0.009 & 350 \\
School and preschool institutions experts & $-0.228^{* *}$ & 0.002 & 181 \\
Social welfare centers experts & -0.036 & 0.511 & 331 \\
Church & $-0.231^{* *}$ & 0.000 & 289 \\
Non-profit organizations & $-0.340^{* *}$ & 0.000 & 225 \\
Municipal authorities representatives & $-0.236^{* *}$ & 0.000 & 270 \\
County authorities representatives & $-0.203^{* *}$ & 0.001 & 243 \\
State authorities representatives & $-0.146^{*}$ & 0.023 & 242 \\
& & & \\
\hline
\end{tabular}

\section{CONCLUSION}

On the basis of the research results and by taking into account the research problems and hypotheses that were set up, we can conclude as follows:

1. There are significant differences in the satisfaction with sources of support and the life satisfaction of people with disabilities according to the following socio-demographic characteristics:

- In terms of the age structure of people with disabilities, it is established that middle aged adults are significantly less satisfied with parents' support compared to younger adults. People with disabilities in late adulthood express a lower level of life satisfaction than the other two groups and find the support of county authorities the least available. 
DRUŠ. ISTRAŽ. ZAGREB GOD. 21 (2012) BR. 1 (115),

STR. 19-38

BLAŽEKA KOKORIĆ, $S$. BERC, G., RUSAC, S.: SATISFACTION WITH
- In terms of the type of disability, it was established that people with multiple disabilities show a significantly lower level of satisfaction with friends' support than people with physical disabilities and hearing impairments. People with multiple disabilities are also significantly less satisfied with life than people with a physical or intellectual disability.

- In terms of the subjective assessment of severity of disability, it is established that people who consider their disability to be serious are the least satisfied with their life and significantly less satisfied with the support they receive from health professionals compared to people who consider their disability to be minor.

- Regarding work status, unemployed and retired people with disabilities express the least satisfaction with life and significantly less satisfaction with the support of relatives than employed people. Moreover, unemployed people with disabilities are significantly less satisfied with the spouse's support.

- According to the criterion of material status among people with disabilities, differences were established in the perception of satisfaction with support of relatives, friends, neighbors, the Church and municipal and county authorities' representatives. People with disabilities who find their material status bad are significantly less satisfied with all the stated sources of support. The criterion of material status proved to be significant in the assessment of life satisfaction, and it was determined that life satisfaction decreases with the decrease of material status.

- People with disabilities who live in cities are more satisfied with the support of relatives, neighbors and non-governmental sector, but the least satisfied with experts' support in school and preschool institutions.

2. There are different levels of significant correlations between life satisfaction and the satisfaction with formal and informal sources of social support among people with disabilities.

- It is established that among all the observed sources of support, except for the support of social welfare centers' experts, there is a significant but a relatively small positive correlation with the assessment of life satisfaction.

The results of this research represent a guideline for creators of social policy, as well as scientists and experts, regarding the need to make stronger formal support systems for people with disabilities, which did not appear to be satisfying. Problems of people with disabilities exist because of the social limitation and social evaluation of the situation, and not because of their difference (Not, 2008). Earlier researches conducted on the territory of Croatia were mostly done on occasional samples, so there is a need for a systematic research on 
DRUŠ. ISTRAŽ. ZAGREB GOD. 21 (2012), BR. 1 (115)

STR. 19-38

BLAŽEKA KOKORIĆ, S., BERC, G., RUSAC, S.: SATISFACTION WITH

NOTES a representative sample and longitudinal monitoring of people with disabilities for the purpose of efficient action and implementation of concrete measures and activities aimed at people with disabilities. In the context of people with disabilities and their families, future researches should include children's experiences and those of other members of family who need help and support, as well as a perspective of experts who provide services, in order to clearly define recommendations for the policy and practice.

${ }^{1}$ In the Republic of Croatia at the national level, there are 80 welfare centers with 27 branch offices (Government of the Republic of Croatia, 2011, 15).

2 According to the Regulations on the composition and work method of bodies for expert evaluation in the procedure of exercising social welfare rights and other rights by special regulations (NN, 64/02), a multiple disability means a combination of two or more disabilities (physical and/or mental).

${ }^{3}$ In the research the medical categorization of different type of disabilities was not used, but an opportunity was given to people with disabilities to express their subjective assessments of the severity of their disability. Through these subjective assessments of serious difficulties, which people with disabilities have in their everyday functioning considering the nature of their disability, the "client perspective" (Urbanc and Ajduković, 2010) was respected.

4 The stated differences in frequencies for a particular source of support are the consequence of large differences in the proportion of respondents who chose the answer "not applicable" in the assessment of satisfaction with a particular source of social support. That kind of answer indicates that respondents had no experience with a particular source of support, and as such are not included in the further analysis.

\section{REFERENCES}

Allen, S. M., Ciambrone, D. and Welch, L. C. (2000), Stage of Life Course and Social Support as a Mediator of Mood State among Persons with Disability. Journal of Aging and Health, 12 (3): 318-341. doi:10. 1177/089826430001200303

Barrera, M., Jr. (1986), Distinctions between Social Support Concepts, Measures, and Models. American Journal of Community Psychology, 14 (4): 413-445. doi:10.1007/BF00922627

Bayley, D. and Gorančić-Lazetić, H. (eds.) (2006), Neumreženi: Lica socijalne isključenosti u Hrvatskoj (Unplugged: Faces of Social Exclusion in Croatia), Zagreb, UNDP, Hrvatska.

Benjak, T., Petreski, N. and Radošević, M. (2010), Izvješće o osobama s invaliditetom u Republici Hrvatskoj (Report on Persons with Disabilities in the Republic of Croatia), Zagreb, Hrvatski zavod za javno zdravstvo, Služba za epidemiologiju kroničnih masovnih bolesti. http://www.hzjz.hr/ epidemiologija/kron_mas/invalidi09.pdf (17. 7. 2010). 
DRUŠ. ISTRAŽ. ZAGREB GOD. 21 (2012), BR. 1 (115),

STR. 19-38

BLAŽEKA KOKORIĆ, S. BERC, G., RUSAC, S.: SATISFAC'TION WITH...
Census of Population of the Republic of Croatia (2001), Zagreb, Državni zavod za statistiku (Croatian Bureau of Statistics).

Chen, R. K. and Crewe, N. M. (2009), Life Satisfaction among People with Progressive Disabilities. The Journal of Rehabilitation, 4 (2). http:// www.thefreelibrary.com/Life + satisfaction + among + people + with + progressive+disabilities.-a0200717519 (13. 7. 2010).

Eden, D. and Aviram, A. (1993), Self-Efficacy Training to Speed Reemployment: Helping People to Helping Themselves. Journal of Applied Psychology, 78 (3): 352-360. doi:10.1037//0021-9010.78.3.352

Government of the Republic of Croatia (Vlada Republike Hrvatske) (2011), Strategija razvoja sustava socijalne skrbi u Republici Hrvatskoj 2011. - 2016. (Strategy of Development of Social Welfare System in the Republic of Croatia 2011 - 2016), Zagreb, Vlada Republike Hrvatske.

Hampton, N. Z. (2001), Disability Status, Perceived Health, Social Support, Self-Efficacy, and Quality of Life among People with Spinal Cord Injury in the People's Republic of China. International Journal of Rehabilitation Research, 24 (1): 69-71.

Janković, J. (2004), Pristupanje obitelji - sustavni pristup (Approaching the Family - A Systematic Approach), Zagreb, Alinea.

Kosor, J. (2006), Akcijski plan Vijeća Europe za promicanje prava i potpunog sudjelovanja u društvu osoba s invaliditetom: poboljšanje kvalitete života osoba s invaliditetom u Europi: 2006. - 2015. (The Council of Europe Action Plan to Promote the Rights and Full Participation of People with Disabilities in Society: Improvement of Quality of Life of People with Disabilities in Europe: 2006 - 2015), Zagreb, Povjerenstvo Vlade Republike Hrvatske i Ministarstvo obitelji, branitelja i međugeneracijske solidarnosti.

Leutar, Z. (2006), Osobe s invaliditetom i siromaštvo (Persons with Disability and Poverty). Revija za socijalnu politiku, 13 (3-4): 293-308. doi:10.3935/rsp.v13i3.428

Leutar, Z. and Milić Babić, M. (2006), Behinderung und Armut Kroatien, Svjetska konferencija: A World Out of Balance - Working for a New Social Equilibrium. IFSW World Conference, 30. 7. - 3. 8. 2006, Munchen.

Leutar, Z., Štambuk, A. and Rusac, S. (2007), Socijalna politika i kvaliteta života starijih osoba s tjelesnim invaliditetom (Social Policy and Quality of Life of Elderly Persons with Physical Disability). Revija za socijalnu politiku, 14 (3-4): 327-346. doi:10.3935/rsp.v14i3.689

Leutar, Z. and Štambuk, A. (2007), Invaliditet u obitelji i izvori podrške (Disability in the Family and Sources of Support). Hrvatska revija za rehabilitacijska istraživanja, 43 (1): 47-61.

Leutar, Z., Ogresta, J. and Milić Babić, M. (2008), Obitelji osoba s invaliditetom i mreže podrške (Families of People with Disabilities and Networks of Support), Zagreb, Sveučilište u Zagrebu, Pravni fakultet.

Leutar, Z. and Milić Babić, M. (2008), Pravo na rad i osobe s invaliditetom u Hrvatskoj (Right to Work and Disabled Persons in Croatia). Sociologija i prostor, 46, 180 (2): 161-186.

Marinić, M. and Brkljačić, T. (2008), Love Over Gold - The Correlation of Happiness Level with Some Life Satisfaction Factors between 
DRUŠ. ISTRAŽ. ZAGREB GOD. 21 (2012), BR. 1 (115)

STR. 19-38

BLAŽEKA KOKORIĆ, S., BERC, G., RUSAC, S.: SATISFACTION WITH...
Persons with and Without Physical Disability. Journal of Developmental and Physical Disabilities, 20 (6): 527-540.

Newsom, J. T. and Schulz, R. (1996), Social Support as a Mediator in the Relation between Functional Status and Quality of Life in Older Adults. Psychology and Aging, 11 (1): 34-44. doi:10.1037//0882-7974.11.1.34

Not, T. (2008), Mentalna retardacija: definicija, klasifikacija i suvremena podrška osobama s intelektualnim teškoćama (Mental Retardation: Definition, Classification and Contemporary Support for Persons with Intellectual Disabilities). Nova prisutnost, VI (3): 339-351.

Penezić, Z. (2006), Zadovoljstvo životom u adolescentnoj i odrasloj dobi (Life Satisfaction at Adolescence and Adulthood). Društvena istraživanja, 15 (4-5): 643-669.

Petrak, O., Despot Lučanin, J. and Lučanin, D. (2006), Kvaliteta starenja - neka obilježja starijeg stanovništva Istre i usporedba s drugim područjima Hrvatske (Quality of Ageing - Some Characteristics of the Elderly Population of Istria and the Comparison with Other Regions of Croatia). Revija za socijalnu politiku, 13 (1): 37-51.

Regulations on the Composition and Work Method of Bodies for Expert Evaluation in the Procedure of Exercising Social Welfare Rights and Other Rights by Special Regulations (Pravilnik o sastavu i načinu rada tijela vještačenja u postupku ostvarivanja prava iz socijalne skrbi i drugih prava po posebnim propisima), Official Gazette (Narodne novine), 64/02.

Sarason, B. R., Shearin, E. N., Pierce, G. R. and Sarason, I. G. (1987), Interrelations of Social Support Measures: Theoretical and Practical Implications. Journal of Personality and Social Psychology, 52 (4): 813-832. doi:10.1037//0022-3514.52.4.813

Urbanc, K. (2005), Medicinski, socijalni ili neomedicinski pristup skrbi za osobe s invaliditetom (Medical, Social or Neomedical Approach to the Care for the Disabled). Ljetopis socijalnog rada, 12 (2): 321-332.

Urbanc, K. and Ajduković, M. (2010), Novi modeli rada centara za socijalnu skrb: izazovi i preporuke (New Models of Social Care Centres: Challenges and Recommendations). Ljetopis socijalnog rada, 17 (3): 353-389.

Verbrugge, L. M. and Yang, L. (2002), Aging with Disability and Disability with Aging. Journal of Disability Policy Studies, 12 (4): 253-267. doi:10.1177/104420730201200405

Wang, C. W., Iwaya, T., Kumano, H., Suzukamo, Y., Tobimatsu, Y. and Fukudo, S. (2002), Relationship of Health Status and Social Support to the Life Satisfaction of Older Adults. The Tohoku Journal of Experimental Medicine, 198: 141-149. doi:10.1620/tjem.198.141

Watson, D., Pichler, F. and Wallace, C. (2010), Second European Quality of Life Survey: Subjective Well-Being in Europe. http://www.eurofound. europa.eu/publications/htmlfiles/ef09108.htm (17. 6. 2010). 
DRUŠ. ISTRAŽ. ZAGREB GOD. 21 (2012)

BR. 1 (115),

STR. 19-38

BLAŽEKA KOKORIĆ, S. BERC, G., RUSAC, S.: SATISFAC'TION WITH
Zadovoljstvo životom te neformalnim i formalnim izvorima podrške kod osoba s invaliditetom

Slavica BLAŽEKA KOKORIĆ, Gordana BERC, Silvia RUSAC

Pravni fakultet, Zagreb

U radu se prikazuju rezultati istraživanja o zadovoljstvu životom te neformalnim i formalnim izvorima podrške kod osoba s invaliditetom u Republici Hrvatskoj. Svrha je rada dati doprinos boljem razumijevanju razlika u zadovoljstvu životom i socijalnom podrškom kod osoba s invaliditetom, ovisno o njihovim specifičnim sociodemografskim obilježjima. Istraživanje je provedeno anketiranjem 689 osoba s invaliditetom. Podaci dobiveni na ponderiranom uzorku od 391 osobe analizirani su metodama deskriptivne statistike, analize varijance, t-testa i korelacijske analize. Rezultati pokazuju da su osobe s invaliditetom najzadovolinije neformalnim izvorima podrške (uža obiteli, prijatelii), a najmanje su zadovoline podrškom neprofitnih organizacija te lokalne i državne vlasti. Utvrđeno je da postoje značajne razlike u zadovoljstvu životom osoba s invaliditetom prema svim promatranim obiliežjima, osim spola i veličine miesta stanovanja, te da je razina njihova zadovoljstva životom značajno povezana s gotovo svim izvorima socijalne podrške.

Ključne riječi: osobe s invaliditetom, socijalna podrška, zadovoljstvo izvorima podrške, zadovoljstvo životom 